\title{
Abusive Supervision Detection as Part of Independent Venture Capital Due Diligence of Management
}

\author{
David A. Blum \\ Walden University
}

\begin{abstract}
Abusive supervision (AS) costs U.S. businesses billions of dollars per year in lost productivity, increased absenteeism, and health care costs. To reduce these costs and to enhance the probability of a successful exist, independent venture capitalists (IVCs) need to be aware of the issue of AS among the management team during the due-diligence process. This study addresses a gap in literature related to IVCs being able to detect AS during duediligence process of the management team. The research question was this: What tools, processes, and methods can IVCs use to detect AS during the due-diligence process of the management team? Four tools, processes, and methods were presented to help reduce the frequency of employee abuse and associated costs.
\end{abstract}

Keywords: abusive supervision, due diligence, independent venture capitalists

\section{Introduction}

This article is based on the supposition independent venture capitalists (IVCs) appear to lack awareness, requisite tools, processes, and methods to identify and understand abusive supervision (AS) occurring in the management team during the due-diligence process. IVCs appear to lack knowledge of the disruptive nature and detrimental effects of AS on competitive advantage of a preportfolio firm (K. J. Harris, Harvey, Harris, \& Cast, 2013; J. Liu, Kwan, Wu, \& Wu 2010; D. Liu, Liao, \& Loi, 2012; Tepper, Duffy, Henle, \& Lambert, 2006). A preportfolio firm is an organization being considered by the IVC for investing but the IVC has not come to terms with company management (Jackson, Bates, \& Bradford, 2012). The cost of AS to U.S. companies is estimated to be over $\$ 24$ billion per year stemming from productivity losses, increased absenteeism, and increased health care costs (J. Liu et al., 2010; D. Liu et al., 2012; Martinko, Harvey, Brees, \& Mackey, 2013; Tepper et al., 2006).

AS affects an estimated 13.6\% of U.S. workers (Palanski, Avey, \& Jiraporn, 2014). By conducting due diligence on the management team related to AS, IVCs might be able to increase profitability, reduce costs, restore trust, and decrease suspicion of management among employees (Tran, Tian \& Sankoh, 2013). To reduce these costs and to enhance the probability of a successful exist, IVCs need to be cognizant of the issue of AS among the management team during the due-diligence process. A successful exit occurs when the IVC realizes a return on investment by selling an interest in the portfolio company via an initial public offering (IPO), acquisition, merger, or sale (Strömsten \& Waluszewski, 2012; Zhang, Aksu, \& Wang, 2012). For the remainder of this article, I provide a statement of the problem and purpose of the research, significance of the research, the research question, methodological approach, literature review, findings, conclusions, and recommendations. 


\section{Statement of the Problem and Purpose}

The problem to be addressed is that IVCs lack tools, processes, and methods to detect AS during the due-diligence process of the management team leading to a successful exit, which occurs when an IVC sells an interest in the portfolio company via an IPO, acquisition, merger, or sale. IVCs appear not to be aware that AS is estimated to cost U.S. companies over $\$ 24$ billion per year (J. Liu et al., 2010; D. Liu et al., 2012; Martinko et al,, 2013; Tepper et al., 2006). IVCs appear not to understand the disruptive nature and detrimental effects of AS on competitive advantage of a preportfolio firm (J. Liu et al., 2010; D. Liu et al., 2012; Tepper et al., 2006). To reduce costs, lower the instances of AS, and to enhance the probability of a successful exit, IVCs must be aware of AS among the management team during the due-diligence process. The purpose of this qualitative study is to increase awareness of AS and offer tools, processes, and methods to help detect AS during the duediligence process of the management team. The goal is to enhance portfolio firm competitive advantage and to provide IVCs with tools, processes, and methods leading to successful exits. AS produces negative outcomes for employees, the organization, and other stakeholders, which can influence IVCs consideration in investing in the preportfolio organization (MacKenzie, Garavan, \& Carbery, 2011). It is hoped that by identifying managers who engage in AS and ameliorating the condition, trust can be restored, suspicion decreased, and blaming others lessened might lead to successful exits, which again, occur when the IVC realizes a return on investment by selling an interest in the portfolio company via an IPO, acquisition, merger, or sale (Strömsten \& Waluszewski, 2012; Tran et al., 2013; Zhang et al., 2012).

\section{Significance of Research}

This research is significant for IVCs to understand AS exists, how to detect AS, and to make more prudent decisions whether to invest in the preportfolio firm. By understanding what AS is and observe instances when conducting due diligence of the management team, IVCs might become more aware of AS and have reduced asymmetry of information whether to invest in the firm. IVCs can use tools, processes, and methods offered in this research during the due-diligence process of the management team to enhance profitability, reduce productivity losses, lower absenteeism rates, and decrease health care costs leading to successful exits.

\section{Research Question}

The primary question driving this research was this: What tools, processes, and methods can IVCs use to detect AS during the due-diligence process of the management team leading to successful exits?

\section{Methodological Approach}

This study is a qualitative review of the extant literature responding to the research question. The method used to review literature is systematic review. Researchers use systematic review in addressing a specific research question derived from the extant literature (Okoli, 2015; Rajaeian, Cater-Steel, \& Lane, 2017). In a systematic review, researchers seek to search for, appraise, and synthesize research evidence focused on and exhaustive and comprehensive search primarily of peer reviewed articles (Glock, Grosse, \& Ries, 2017). In a systematic review, the researcher aims to understand what is known and what still is unknown, uncertainty of the findings, recommendations 
for further research, and recommendation for practice (Glock \& Grosse, 2015; Glock et al., 2017). Researchers use systematic review to provide an objective approach toward reducing bias (Bearman \& Dawson, 2013). The review helps researchers identify and critically appraise pertinent research by collecting, analyzing, and reporting results from peered and non-peered-reviewed information (Hochrein, Glock, Bogaschewsky, \& Heider, 2015). Of the 80 resources used in this article, 75 (94\%) came from peer-reviewed published articles, and five (6\%) came from from dissertations, books, and websites. Criteria for inclusion and exclusion of resources focused on the research question and available resources. Articles, books, dissertations, and authoritative websites written in English pertaining to independent venture capital, AS, and due diligence published between 2000 and 2017 were included. Included studies were considered acceptable contingent upon research conducted and analyses provided with representative and reasonable sample size meeting reliability and validity criteria published with major academic outlets whenever possible (Glock \& Grosse, 2015; Glock et al., 2017). Nonauthoritative websites, blogs, wikis, articles not written in English, and articles outside the focus of the research question were excluded.

Five steps exist in systematic review. First, the researcher frames the research question(s) for review (Khan, Kunz, Kleijnen, \& Antes, 2003, Knoll, 2017). For this study, the research question is this: What tools, processes, and methods can IVCs use to detect AS during the due-diligence process of the management team leading to successful exits? Key terms used were abusive supervision, abusive supervision detection, due diligence, due-diligence processes, due-diligence tools, due-diligence methods, independent venture capitalists, management due diligence, independent venture capital decisionmaking, and management assessment of independent venture capital decision-making. Key terms were identified by a review of the literature.

The second step is to find relevant studies (Khan et al., 2003; Knoll, 2017). For this study, academic resources were accessed from (a) EBSCOhost, (b) ProQuest, (c) ScienceDirect, (d) Academic Search, (e) ABI/INFORM, (f) Emerald, (g) Springer, (h) SAGE Journals, (i) John Wiley and Sons, and (j) Taylor and Francis.

The third step is to assess the quality of the studies (Khan et al., 2003; Knoll, 2017). Journals used in this article were assessed under the assumption the peer-review process is a reliable indicator that the literature review, research methods, threats to validity, and the accuracy of reporting of findings/results were addressed and are acceptable by a thorough examination of at least two independent experts in the same field. I reviewed as many peer-reviewed articles as possible to collect data to minimize bias. Researcher bias and confirmation bias were assessed as potential threats in this article. Researcher bias was mitigated by identifying inclusion criteria for primary studies. Criteria included data related to IVCs, due diligence, and AS. Confirmation bias was a threat to article retrieval and data analysis because I could have a specific belief on the effects of AS relative to IVC due diligence of the management team. To mitigate confirmation bias, I continually reevaluate impressions from data presented in the articles and challenged my preexisting assumptions.

The fourth step is to summarize the evidence (Khan et al., 2003; Knoll, 2017). Evidence was derived from the extant literature. No primary data were collected for this study. The search strategy was to use databases such as (a) EBSCOhost, (b) ProQuest, (c) ScienceDirect, (d) Academic Search, (e) ABI/INFORM, (f) Emerald, (g) Springer, (h) SAGE Journals, (i) John Wiley and Sons, and (j) Taylor and Francis. Quantitative, qualitative, and mixed-methods articles were included. Some non-peer- 
reviewed articles were selected when relative peered articles were unavailable. Articles and books that did not pertain to IVC, due diligence, AS, management assessments, elements of a successful exit, tools, processes, and methods to detect AS were eliminated. Information was retrieved related to AS, IVCs, factors informing IVC decision-making, management assessment of IVC decision-making, and management due diligence.

The fifth step is to interpret findings (Khan et al., 2003; Knoll, 2017). An interpretation of findings is offered in the results section. Data was analyzed and synthesized from the extant literature. As outlined in the research literature and in the rest of this article, an indication in the literature is AS can have a negative outcome on organizational performance, competitive advantage, and success. It is expected the literature review will provide sufficient information to respond effectively to the research question.

\section{Literature Review}

\section{Abusive Supervision}

AS is considered as the routine and sustained display of verbal and nonverbal behaviors exhibited publicly or privately by managers in which the employee perceives as threatening, bullying, or humiliating (Lui et al., 2012; Mawritz, Mayer, Hoobler, Wayne, \& Marinova, 2012; Tepper, 2000; Tepper, Moss, \& Duffy, 2011). Examples of verbal and nonverbal behaviors include (a) being rude, (b) acting in a coercive manner, (c) making derogatory comments, (d) spreading rumors, (e) withholding information, (f) taking undue credit for an employee's work, (g) invading privacy, and (h) giving an employee the "silent treatment" (Chan \& McAllister, 2014; Lui et al., 2012). The recipient of AS often exhibits (a) burnout, (b) anxiety, (c) work withdrawal, (d) insomnia, (e) fear, and (f) psychological exhaustion (Chan \& McAllister, 2014; Mackey, Ellen, Hochwarter, \& Ferris, 2013; Tepper, 2000). Employees who have an abusive supervisor deal with (a) job tension, (b) public criticism, (c) loud and angry tantrums, (d) inconsiderate actions, (e) paranoia, and (f) distrust (Chan \& McAllister, 2014; Mackey et al., 2013; Tepper, 2000). AS is not an issue of "one bad apple" or a one-time occurrence but is a routine, consistent, and complex interaction pattern between management and employees (Hoobler \& Hu, 2013). AS often starts with managers and filters to employees (Mawritz et al., 2012). Employees often imitate the behaviors experienced from managers (Pearce \& Manz, 2014).

AS is a subjective assessment because one or more persons could interpret a manager's behavior as abusive in one setting yet nonabusive in another context (Harvey, Harris, Gillis, \& Martinko, 2014). An employee's psychological and social adaptive perceptions might be instrumental in detecting abuse (Mackey et al., 2013). Kacmar, Whitman, and Harris (2013) suggested work environments are often unpredictable and might create feelings of uncertainty of employees' future with the organization. Employees who experience AS often feel the organization does not recognize their value, become dissatisfied with the job, and intend to quit (D. Liu et al., 2012). AS diminishes an employee's motivation to excel and reduces creativity resulting in productivity loses (D. Liu et al., 2012). Employees victimized by AS often encounter decreased overall life and job satisfaction and have higher instances of work/family conflicts (Mackey et al., 2013).

To cope with AS, useful strategies include (a) ingratiation, (b) communication, (c) avoidance, (d) talking to others, and (e) engaging in reassuring thoughts (Yagil, Ben-Zur, \& Tamir, 2010). However, Yagil et al. found most coping strategies are ineffective in reducing AS. Abused employees often use 
avoidant or active coping strategies. Avoidant coping takes the form of physically and psychologically removing oneself from the situation, maintaining physical distance between the employee and manager, not coming to work, and/or increased reliance on drugs and alcohol (Tepper et al., 2006). Active coping is communicating AS experiences to the manager (Tepper et al., 2006). Tepper noted employees who are subjected to AS are more likely to use avoidant coping than active coping. However, active coping is deemed a more effective coping mechanism (Tepper et al., 2006).

Extant research suggested AS is negatively associated with job satisfaction (Glambek, Matthiesen, Hetland, \& Einarsen, 2014; Velez \& Neves, 2017), organizational commitment (Glambek et al., 2014; Shoss, Eisenberger, Restubog, \& Zagenczyk, 2013), and positively related to intentions to quit (Glambek et al., 2014). Tepper, Moss, Lockhart, and Carr (2007) found perceived AS experiences mediated the effects of AS on employees' attitudes. Glambek et al. noted experiences of irritation and the fear derived from AS related to aggressive behaviors in employees. AS has been linked with deviant organizational behaviors such as ridicule or giving the silent treatment; actions violating organizational norms, and behaviors and actions that might threaten the organization and/or employees (Thoroughgood, Tate, Sawyer, \& Jacobs, 2012).

Mitchell and Ambrose (2007) found a positive relationship between AS and supervisor-directed deviance. Mitchell and Ambrose argued supervisor-directed deviance often takes the form of acting rudely. Supervisor-directed deviance can be construed as interpersonal deviance where the supervisor plays pranks or says hurtful words to employees (Martinko et al., 2013). Supervisordirected deviance can also be acts of fraud and or theft against the company (Ahmad \& Omar, 2013).

The relationship between AS and supervisor-directed deviance is greater among employees who subscribed to the concept of tit-for-tat (Mackey, Frieder, Perrewe, Gallagher, \& Brymer, 2015). In such a scenario, abused employees often retaliate against the abusive supervisor in an aggressive manner and resent management other employees within the organization (Mackey et al., 2015). Aryee, Sun, Chen, and Debrah (2008) found AS was related to abused employees' job performance and sense of self-esteem. Aryee et al. found abused employees whose self-esteem was low, AS was unrelated to employee deviance behavior; however, for employees with high self-esteem, AS was positively related to work deviance.

Challenges exist associated with studying AS. Tepper (2000) mentioned researchers often rely on subjective reports to measure AS. A problem with subjective reports is some people might underestimate the level of AS exposure from an unwillingness to admit to have been victimized while others might exaggerate management behavior (Shoss et al., 2013). A related complication is gathering data from abused employees who are unwilling self-identified (Tepper et al., 2006).

AS can result in high costs, create disruption, and have detrimental effects on the competitive advantage of a preportfolio firm. Abusive managers put organizations at a competitive disadvantage (Allen, Bryant, \& Vardaman, 2010). Employees who must work with an abusive supervisor often refuse to conform to the supervisor's instructions and are unconcerned about consequences associated with not conforming to management compliance standards (Tepper et al., 2006). 


\section{Independent Venture Capitalists}

\section{Overview}

IVCs invest in new, high growth, high risk, and market scalable companies known as portfolio firms (Blum, 2015; Olsson, Frydenberg, Jakobsen, \& Jessen, 2010). IVC firms are the dominant source of equity funding for new entrepreneurial, market scalable, high-growth, high-risk, and early-stage high-technology business ventures (Jackson et al., 2012; Li \& Zahra, 2012; Olsson et al., 2010; Schertler \& Tykvova, 2011). In addition to equity funding and attempting to maximize return on investment, IVCs provide managerial services, strategic advice, sit on boards, monitor management actions, hire key personnel, engage with strategic partners, and provide access to extensive networks of potential customers and suppliers (Bhagat, 2013; Rajan, 2010).

The goals of the IVC are to create value for high net worth investors and to complete a successful exit (Jackson et al., 2012; Li \& Zahra, 2012; Olsson et al., 2010; Schertler \& Tykvova, 2011). IVCs rarely take over a portfolio firm preferring to liquidate investments at a future date via an exit (Bhagat, 2013). The IVC adds value during the exit process by helping to locate investment bankers and to present the portfolio company to public investors (Rajan, 2010). IVCs expect to generate 30\% to $50 \%$ annual growth before agreeing to additional funding (Lehtonen \& Lahti, 2009). The IVC investment carries no guarantee of a return on investment (Rajan, 2010).

IVCs comb through thousands of business plans yearly searching and scrutinizing firms having the highest probability of achieving a successful exit (Bhagat, 2013). Once a firm is selected for potential investment, the IVC will conduct due diligence. As part of due diligence, IVCs meet with management teams, valuate performance metrics, discern market scalability, and determine whether the company's product(s) or service(s) meet an everyday need among other factors (Blum, 2013). The focus of this study is due diligence of the management team pertaining to AS.

IVC firms fill a critical intermediary function by not only providing equity funding to high risk, market scalable, high growth portfolio firms, but creating value for high net worth investors (Jackson et al., 2012; Olsson et al., 2010; Schertler \& Tykvova, 2011). Zhang et al. (2012) found that IVC firms play a critical role is positively shaping new firms. Rather than taking over a firm, IVCs prefer to liquidate investments in portfolio companies at a future date usually through an IPO, sale, merger, or acquisition (Zhang et al., 2012).

The proportion of companies that receive IVC funding is very small (Rajan, 2010). While the United States leads the world in IVC firms, IVC firms are not a major source of capital for small businesses (Rajan, 2010). Although IVC firms receive more than 1,000 requests for funding annually (Cumming, Schmidt, \& Walz, 2010), Kaplan and Lerner (2010) indicated that only one sixth of $1 \%$ of new businesses obtain IVC funding. Factoring for the growth of the economy and the stock market, Rajan (2010) and Jackson et al. (2012) inferred that the availability of IVC funding has increased steadily over the years because IVC investing in early stage companies has a lower likelihood of reaching an exit. Jackson et al. espoused that new IVC firms have elevated financial risks compared to those of firms with a proven performance record. 


\section{Factors Influencing Independent Venture Capital Decision-Making}

The venture capital investment process involves several judgments and decision-making considerations made under uncertainty and asymmetry of information (Li \& Zahra, 2012; Zhang, 2011). Key factors that determine IVC investment decision-making process focus on the (a) entrepreneur's personality, (b) entrepreneur's experience, (c) the organization's products and services, (d) organization's market or industry, (f) financial considerations, (g) risks, (h) valuation, (i) portfolio size and scope, (j) management skills, and (k) exiting (Dhochak \& Sharma, 2016). The entrepreneur's personality/chemistry is the probably most significant factor of the IVCs investment decision (Blum, 2015). IVCs look for amicable personality, honesty and honesty above other characteristics such as leadership quality, a do what it takes attitude, integrity, confidence and commitment (Blum, 2015). IVC firms carefully review personal chemistry with the preportfolio management team, as the parties may be working with each other for several years (Blum, 2015). Looking beyond the management team, the IVC needs to evaluate the attractiveness and risks of the investment opportunity, considering factors as market size, strategy, technology, customer adoption, competitive advantage, quality, and the industry experience of the management team (Blum, 2013). Preportfolio firms generally do not have an established credit history, forcing the firm to seek IVC capital assistance (Blum, 2015). The analysis conducted by the IVC firm focuses on assessing the capabilities of the management team of the preportfolio firm (Gaddya, Sivaram, Jones, \& Wayman, 2017). IVCs invest billions of dollars in first-round equity financing for new ventures each year, and investment screening is the primary method used to decide which entrepreneur to fund (Jia \& Wang, 2017).

The entrepreneur's experience is another noteworthy consideration in the investment decisionmaking process. An entrepreneur should have a managerial record of success, has start-up experience, deep product market/industry expertise, and business acumen (Dhochak \& Sharma, 2016). The products and services offered are critical to an investment decision. The product or service should serve an everyday need yet be innovative, scalable, patentable, and exhibits a clear competitive advantage (Blum, 2013). Market is a key consideration in investment decision-making (Dhochak \& Sharma, 2016).

IVCs typically invest in portfolio firms that exhibit long-term, little liquidity, high-risk equity with the promise of high return on investment (Rajan, 2010). IVCs invest at the early as well as later stages in the portfolio firm's life cycle (Rajan, 2010). Most IVCs view an IPO as the preferred exit strategy with the central goal to achieve the highest ROI to increase shareholder value and market valuation for the portfolio firm (Rajan, 2010). In this respect, a strategic trade-off exists between aiming for growth or profitability of the portfolio firm (Rosenbusch, Brinckmann, \& Muller, 2013). Portfolio firms favor growth, while IVCs favor profitability (Blum, 2015). Generally, IVC-funded firms strive to become market leaders in fast growth markets to command a premium at the IPO (Dhochak \& Sharma, 2016).

Risk and returns are directly proportional to each other. IVCs investment always has an estimation of systematic risk or beta within its venture (Dhochak \& Sharma, 2016). R. S. Harris, Jenkinson, and Kaplan (2014) noted a fund's portfolio diversification model and estimated an average $\beta$ of 1.12 for venture funds. IVCs consider riskiness of a venture while taking investing decision (Dhochak \& Sharma, 2016). 
Several considerations influence the valuation of IVC investments. Valuations occur only when a portfolio company has refinanced a loan or anticipate an exit event (Korteweg \& Sorensen, 2010). Bartkus and Hassan (2009) indicated that portfolio companies in California and Massachusetts had higher rates of capital inflows than portfolio firms did in other states. In addition, most IVC firms and IVC funding in the United States occurs in California or Massachusetts (Bartkus \& Hassan, 2009).

The IVC members decide the funding level for portfolio firms based on the facts gathered during the screening, negotiation, and due-diligence process. In exchange for providing capital funding, the IVC expects the portfolio firms to generate $30 \%$ to $50 \%$ annual growth in value before agreeing to capitalize subsequent funding stages (Lehtonen \& Lahti, 2009). The challenge for both parties is that IVCs view portfolio firm valuations as unrealistic, while the portfolio firms interpret IVCs' valuations as unreasonably stringent (Lehtonen \& Lahti, 2009).

High volatility from valuations in public equity markets mixed with economic and competition uncertainties are rampant in the IVC industry (Blum, 2013). An increase in IPO valuations often prompts younger IVCs to raise more funds from investors (Blum, 2013). A statistically strong correlation exists between the rate of return of IVC funding and the overall market returns (Guo, Lou, \& Pérez-Castrillo, 2015).

IVCs prefer to invest in a portfolio rather than a single investment, which ultimately affects their investment strategies and returns. Buraschi, Porchia, and Trojani (2010) found that marginal returns are dependent on the optimal portfolio size, whereas Fulghieri and Sevilir (2009) concluded that portfolio size inversely related to the start-ups potential and riskiness (i.e., IVCs prefer larger portfolio when ventures have the low potential and high risk and vice versa). Dhochak and Sharma (2016) mentioned that an investor has the limited ability to add value in new venture, so they have to consider the size and scope of the portfolio accordingly.

Anticipating a success exit is the most crucial factor of an investment decision-making, because it is directly proportionate to the returns. Thus, IVCs follow the number of pre-and postinvestment activities for successful exit. Possibly the most critical value addition that an IVC can provide to the portfolio firm is enabling the IPO, strategic merger, sale, or acquisition (Rajan, 2010). Large private equity and IVC investors have well-connected networks and possess an in-depth understanding of the capital markets (Rajan, 2010). Therefore, if the portfolio company wants to list as an IPO, acquiring the best merchant banker and the ability to value the portfolio firm correctly is vital to raising the expected funds (Rajan, 2010). The IVCs' goal throughout the entire investment process is to focus on achieving large financial returns on investments (Rajan, 2010). Dhochak and Sharma (2016) argued exit strategies are equally significant at the initial screening process of a proposal.

\section{Management Assessment of Independent Venture Capital Decision-Making}

Venture capitalists realize that they are often betting on people when they make investment decisions hoping their assessments of portfolio firm personnel are accurate (Blum, 2015). The purpose of due diligence is to determine which business plans can eventually lead to a successful exit by lessening adverse selection and reducing asymmetry of information between the preportfolio company and the IVC (Flyvbjerg, 2013). Due diligence encompasses all activities deemed necessary to evaluate an investment proposal (Sammut, 2012; Simic, 2015). Due diligence is measured by the 
total hours expended by the IVC conducting research on the portfolio firm (Flyvbjerg, 2013). Flyvbjerg noted the time spent on due diligence is generally commensurate with the expected funding size.

Each year, about $15 \%$ of business plan submissions reach the due-diligence stage (Metrick \& Yasuda, 2011; Simic, 2015). From these 15\%, only 5\% are considered suitable for investment and enter negotiation (Metrick \& Yasuda, 2011; Simic, 2015). IVCs usually invest in less than $3 \%$ of business plans submitted (Metrick \& Yasuda, 2011; Simic, 2015).

During the due-diligence process, IVCs focus on reducing market, technology, management, and governmental uncertainty (Blum, 2014). Because individuals are instrumental to success or failure of a business, IVCs desire no uncertainty about the veracity and intentions of the management team to advance a sustainable organization (Blum, 2014). In addition to the management team, duediligence research is conducted on current and predicted market and economic conditions, technology adoption and challenges, regulatory environment, and competitive advantage (Lehtonen \& Lahti, 2009). Although not an all-inclusive list, as part of the due-diligence process, IVCs (a) analyze current and past financial statements, (b) review market comparables to determine valuation price, (c) conduct varying market analysis, (d) review competitive advantage and market trends, (e) determine whether the technology is disruptive and scalable, (f) decide whether the technology meets an everyday need, (g) review provisional and approved patents, (h) review any pending legal action, and (i) analyze local, state, and or federal regulatory issues (Blum, 2014; Lehtonen \& Lahti, 2009).

The time to complete due diligence varies from 3 to 6 months (Lehtonen \& Lahti, 2009). IVCs who conduct extensive due diligence are more involved with supporting the portfolio firm realize higher return on investment through a successful exit (Blum, 2014; Lehtonen \& Lahti, 2009). Due diligence is not just about empirical data but also qualitative factors.

IVCs often rely on "gut feelings," personal chemistry, and value personal relationships with the management team (Blum, 2014). IVCs want absolute confidence management understands the technology, industry standards, and market demand before investing. Using qualitative and quantitative factors, IVCs determine the length of involvement with the portfolio firm. Generally, IVCs seek a 3- to 5-year relationship before exiting (Blum, 2014). Based on due diligence, IVCs can determine valuation and funding requirements to achieve a successful exit based on high return on investment. Funding usually starts at $\$ 10$ million and can go up to $\$ 100$ million or more through funding phases (Blum, 2014).

During the due-diligence process, IVC firms focus on reducing investment risk. Before making a financial investment, the IVC firm performs extensive research on the preportfolio firm's product line, management team, and internal and external competitive environments (Blum, 2014; Lehtonen $\&$ Lahti, 2009). Due diligence is measured by the total hours spent performing research on the preportfolio company (Lehtonen \& Lahti, 2009).

IVC firms will review pending legal action, provisional and approved patents, market potential and strategy, the competitive environment, and the portfolio firm's competitive advantage (Lehtonen \& Lahti, 2009). The time spent by IVCs doing due diligence is generally proportionate to the anticipated investment funding size (Blum, 2015). According to Lehtonen and Lahti (2009), the time from screening to early funding is approximately 6 months. Yung (2009) countered that the average was closer to 3 months. Either way, raising IVC funds is time-consuming and difficult. IVC firms 
who perform extensive due diligence, and are more involved in the postinvestment operations of the portfolio firm experience, significantly higher ROI through a successful exit (Lehtonen \& Lahti, 2009). Lehtonen and Lahti stated IVCs who focused on early funding opportunities experienced few negative exits.

\section{Management Due Diligence}

Due diligence of the management team is crucial to deciding whether AS exists within the preportfolio firm. Management due diligence is the process of evaluating and assessing the effectiveness of the management team's ability to achieve strategic objectives and manage risk (Dobre, 2013). A consequence of IVC mistakes during managerial due diligence can mean the difference between competitive advantage of the firm with a successful exit or sudden failure resulting in bankruptcy (Dobre, 2013).

IVCs use management due-diligence processes to (a) ensure sustainable profit and growth for organizations, (b) increase the chance of good returns on investment by reducing risk, (c) understand strengths and weaknesses, (d) efficiently appraise the management team, and (e) assess management team members' abilities to reach common goals (Benoliel, 2015; Boyle, Parmeter, Boehlert, \& Paterson, 2013; Flyvbjerg, 2013). Managerial due diligence identifies undiscovered threats that might affect productivity such as unacknowledged motives, AS, or personal conflicts between individual managers (Delak \& Bajec, 2013). Management due diligence provides IVCs with a foundation of knowledge for assessing the management team and individual manager performance (Cooper, 2015). Based on due diligence, the IVC can determine whether nonconforming managers need training or retraining or if they need to be dismissed to achieve organizational goals (Cooper, 2015).

The basis of due diligence of the management team is the understanding that significant tacit knowledge exists with the individual manager, not necessarily in the firm's documented processes, procedures, and policies (Cooper, 2015). Traditionally, the most important aspect of the evaluation of the portfolio company for the IVC is the experience and personality of the management team (Nunes, Félix, \& Pires, 2011). Characteristics IVCs look for in the management team are (a) hard workers, (b) good delegators, (c) strategic thinkers with vision, and (d) an understanding of the organization's technology and market (Nunes et al., 2011). Knowledge of AS is also important for the organization to remain competitive as abusive managers contribute to productivity losses, increased absenteeism, increased health care costs, and lost trust. Over the course of the relationship with the portfolio firm, IVCs continually evaluate the management team noticing significant changes in the character of the team and organizational performance.

IVCs place importance on the quality of management because IVCs understand the business environment will change, and management must be able to effectively react to competitive internal and external threats, varying customer demands, new regulations, and other market and technology dynamics. Having an abusive supervisor can negate the quality of the management team potentially placing the competitive of the IVC investment at higher risk (Allen et al., 2010; Nunes et al., 2011). Ensuring management is making correct tactical and strategic decisions are vital for the organization's success. IVCs want to ensure the management team can meet and overcome challenges and not engage in deviant behaviors. If IVCs realize management teams are incomplete

International Journal of Applied Management and Technology 
or a team member is nonconforming to company and societal standards of conduct, IVCs will often recruit additional key talent (Blum, 2015).

\section{Results}

Because of high costs, disruptive nature, and detrimental effects of AS on the competitive advantage of a preportfolio firm, IVCs need to be aware the effect AS has on employees and management. In response to the research question: What tools, processes, and methods can IVCs use to detect AS during the due-diligence process of the management team leading to successful exits, I explored relevant tools, processes, and methods. My findings indicated IVCs could (a) use a 360-degree feedback program, (b) conduct detailed background checks on the management team, (c) assess the management team for AS, and (d) observe management in action. Given the significant costs abusive managers can have for organizations, senior management is well advised to ameliorate and when possible eliminate AS.

\section{0-Degree Feedback}

IVCs could use a 360-degree feedback program during the due-diligence process to observe whether the management culture fosters civility among management and employees (Tepper et al., 2006). The 360-degree feedback program is a system where subjects receive confidential and anonymous feedback from managers, peers, and direct reports (Manning, 2013; Tee \& Ahmed, 2014). Normally, between eight and 12 people fill out an anonymous online feedback form with questions covering a comprehensive range of workplace competencies (Manning, 2013). Responses are rated on a scale from 1 (very satisfied) to 5 (very dissatisfied), with a provision for written comments (Manning, 2013). The subject of the feedback fills out a self-rating form with the same questions asked of managers, peers, and direct reports (Manning, 2013). Managers use 360-feedback data to obtain a better understanding of the strengths and weaknesses of employees and other managers (Tepper et al., 2006). Using the 360-degree feedback program helps to identify deviant behaviors such as AS in individuals (Tee \& Ahmed, 2014).

\section{Conduct Background Checks}

As part of due diligence, IVCs often request a list of references to contact and learn more about management's background and confirm whether the team might be financially backed (Brisbourne, 2011). As part of this background examination, IVCs could find occurrences of AS. Through the management due-diligence process, IVCs develop an understanding of the primary gaps in the management team. For AS, IVCs could review (a) the founders and their backgrounds (what is true, what is not true); (b) disclosures of mental health issues; (c) disclosures of past and current employee complaints; (d) employee confidentiality agreements; (e) past and current performance evaluations; (f) experience commensurate with position; (g) investigative reports on all principals, managers, and directors for instances of AS; (h) credit history reports on all principals, managers, and directors (specifically looking for lawsuits placement on government registries and abnormal transactions related to deviant behaviors); and (i) resume/curriculum vitae verification on all principals, managers, and directors (Nunes et al., 2011). 


\section{Assess the Management Team for AS}

IVCs need to ask and receive satisfactory responses as to whether (a) managers exhibit a capacity for sustained effort (DeCleyn \& Braet, 2007); (b) the management team is flexible or rigid in its orientation (MaRS, 2013); (c) management skills and personalities exhibit any signs of AS (MaRS, 2013); (d) the number of employees, turnover, absentee problems, and hiring projections indicate AS is present (MaRS, 2013); (e) any manager is seen as an outlier (DeCleyn \& Braet, 2007); (f) personality conflicts and or mismatches exist within the management team (MaRS, 2013); (g) critical resources managers have access to bank accounts (MaRS, 2013); and (h) managers evaluate risk well (DeCleyn \& Braet, 2007).

IVCs could use Tepper's (2000) 15-item scale to assess for AS. Tepper's scale consists of items prefaced with the statement, "My boss..." Respondents use the following 5-point response scale: 1 (I cannot remember him/her ever using this behavior with me), 2 (He/she very seldom uses this behavior with me), 3 (He/she occasionally uses this behavior with me), 4 (He/she uses this behavior moderately often with me), and 5 (He/she uses this behavior very often with me; Tepper, 2000, p. 189).

The items were as follow: (1) ridicules me, (2) tells me my thoughts or feelings are stupid, (3) gives me the silent treatment, (4) puts me down in front of others, (5) invades my privacy, (6) reminds me of my past mistakes and failures, (7) doesn't give me credit for jobs requiring a lot of effort, (8) names me to save himself/herself embarrassment, (9) breaks promises he/she makes, (10) expresses anger at me when he/she is mad for another reason, (11) makes negative comments about me to others, (12) is rude to me, (13) does not allow me to interact with my coworkers, (14) tells me I'm incompetent, and (15) lies to me (Tepper, 2000, pp.189-190).

\section{Observe the Management Team in Action}

IVCs must observe how managers interact with employees when conducting due diligence on the management team. IVCs might notice whether a manager is demeaning (Bowling \& Michel, 2011). The IVC need to notice if a manager is verbally disrespectful, belittles, or humiliates an employee (Duffy, Ganster, \& Pagon, 2002). The IVC could notice if a manager is controlling and isolates employees (Michel, Newness, \& Duniewicz, 2016). IVCs might review policies and procedures to ensure conformance to standards (Mitchell, Vogel, \& Folger, 2015). The IVC could notice if the manager appears to lack confidence in employees by closely reviewing every detail of an employees work such as wanting to see each e-mail sent and why and when the employee left his or her desk (Tepper et al., 2011). The IVC could see if managers attempt to isolate employees from others (Duffy et al., 2002). IVCs could observe whether managers trust employees by noticing the manager closely watching what an employee does (Michel et al., 2016). IVCs need to notice if the manager speaks unfavorably about an employee or former employees especially in front of coworkers (Bowling \& Michel, 2011). The IVC needs to speak with and interview a representative sample of employees to decide if a manager exhibits AS (Nunes et al., 2011).

\section{Study Limitations}

The primary limitation of this study was scant extant research exists identifying IVCs being able to detect AS during due-diligence process of the management team. This limitation was ameliorated by the use of research available pertaining to IVCs and AS. Individually abundant literature exists on 
IVCs and AS but not specifically IVCs being able to detect AS during due-diligence process of the management team. The second limitation was in not using primary data collection methods used such as interviews, surveys, and questionnaires. IVCs being able to detect AS during due-diligence process of the management team is unexplored and underexplored therefore the likelihood IVCs would be able to sufficiently address the research question was deemed nil. The third limitation was that the selection of the main research databases related to the topic. I am unable to guarantee all AS, IVC, due-diligence articles in the extant were selected for review. The fourth limitation was that I did not in applying the systematic literature method perform forward searches due to temporal and resources constraints.

\section{Conclusions and Recommendations}

Finding AS among management is difficult because AS is a subjective assessment based on an employee's perceptions and within the context of the work environment (Tepper, 2000). Because of the high cost associated with AS, IVCs and senior management at portfolio firms need to be educated on the potential impacts of AS on staff to mitigate the effects of abuse and associated costs. In this exploratory research, I provided information to bring awareness of AS to IVCs and offered tools, processes, and methods IVCs can use to detect AS when conducting due diligence on the management team. I answered the following research question: What tools, processes, and methods can IVCs use to detect AS during the due-diligence process of the management team leading to successful exits? My findings indicated IVCs need to (a) implement a 360-degree feedback program, (b) conduct detailed background checks on the management team, (c) assess the management team for AS, and (d) observe the management in action.

IVCs might become cognizant of AS. Otherwise, the portfolio company might experience (a) lower employee retention rates, (b) higher employee turnover, (c) lower morale, (d) lower job satisfaction, (e) diminishing trust of managers, which can create (f) conflict between work and family obligations, (g) lessened commitment to the organization affecting organizational success, and (h) higher risk of an unsuccessful exit. Managers could establish healthy working relationships to help ensure competitive advantage of the company.

Regarding future research, I recommend follow-up research as to the specific instances related to awareness of AS among IIVCs. Quantitative research should be considered for examining whether a relationship exists between AS and management review and/or performance during due diligence. Researchers should consider qualitative research by conducted interviews of IVCs to understand whether IVCs are open to or use the findings from this study when conducting due diligence of the management team.

\section{References}

Ahmad, A., \& Omar, Z. (2013). Abusive supervision and deviant workplace behavior: The mediating role of work-family conflict. The Journal of Human Resource and Adult Learning, 9, 124130.

Allen, D. G., Bryant, P. C., \& Vardaman, J. M. (2010). Retaining talent: Replacing misconceptions with evidence-based strategies. Academy of Management Perspectives, 24, 48-64. 
Aryee, S., Sun, L. Y., Chen, Z. X. G., \& Debrah, Y. A. (2008). Abusive supervision and contextual performance: The mediating role of emotional exhaustion and the moderating role of work unit structure. Management and Organization Review, 4, 393-411. doi:10.1111/j.17408784.2008.00118.x

Bartkus, J. R., \& Hassan, K. (2009). Specialization versus diversification in venture capital investing. Journal of Financial Regulation and Compliance, 17, 134-145. doi:10.1108/13581980910952577

Bearman, M., \& Dawson, P. (2013). Qualitative synthesis and systematic review in health professions education. Medical Education, 47, 252-260. doi:10.1111/medu.12092

Benoliel, M. (2015). Hazards to effective due diligence. Eurasian Journal of Business and Management, 3, 1-7. doi:10.15604/ejbm.2015.03.01.001

Bhagat, S. (2013). Why do venture capitalists use such high discount rates? The Journal of Risk Finance, 15, 94-98. doi:10.1108/JRF-08-2013-0055

Blum, D. A. (2013). Exploring best practice skills to predict uncertainties in venture capital investment decision-making (Doctoral dissertation). Available from ProQuest Dissertations \& Thesis. (UMI Number: 3588186)

Blum, D. A. (2014). A venture capital handbook: Best practice strategies for investing in microalgae biodiesel. Huntsville, AL: Emerson Street Press.

Blum, D. A. (2015). Factors contributing to independent venture capital successful exits. Journal of Business and Economics Research, 13, 1-6. doi:10.19030/jber.v13i1.9074

Bowling, N. A., \& Michel, J. S. (2011). Why do you treat me badly? The role of attributions regarding the cause of abuse in subordinates' responses to abusive supervision. Work \& Stress, 25, 309320. doi:10.1080/02678373.2011.634281

Boyle, K. J., Parmeter, C. F., Boehlert, B. B., \& Paterson, R. W. (2013). Due diligence in metaanalyses to support benefit transfers. Environmental and Resource Economics, 55, 357-386. doi:10.1007/s10640-012-9630-y

Brisbourne, N. (2011). 50 questions: How does a VC evaluate management teams? Retrieved from http://www.theequitykicker.com/2011/04/20/50-questions-how-does-a-vc-evaluate-amanagement-team/

Buraschi, A., Porchia, P., \& Trojani, F. (2010). Correlation risk and optimal portfolio choice. Journal of Finance, 65, 393-420. doi:10.1111/j.1540-6261.2009.01533.x

Chan, M. E., \& McAllister, D. J. (2014). Abusive supervision through the lens of employee state paranoia. Academy of Management Review, 39, 44-66. doi:10.5465/amr.2011.0419

Cumming, D., Schmidt, D., \& Walz, U. (2010). Legality and venture capital governance around the world. Journal of Business Venturing, 25, 54-72. doi:10.1016/j.jbusvent.2008.07.001

DeCleyn, S. H., \& Braet, J. (2007). The due-diligence process: Guiding principles for early stage innovative products and venture capital investments. The Journal of Private Equity, 10, 4351. doi:10.3905/jpe.2007.686429 
Delak, B., \& Bajec, M. (2013). Framework for the delivery of information system due diligence. Information Systems Management, 30, 137-149 doi:http://dx.doi.org/10.1080/10580530.2013.773806

Dhochak, M., \& Sharma, A. K. (2016). Using interpretive structural modeling in venture capitalists' decision-making process. Decision, 43, 53-65. doi:10.1007/s40622-015-0106-0

Dobre, O.-I. (2013). Employee motivation and organizational performance. Review of Applied SocioEconomic Research, 5, 53-60. Retrieved from ftp://ftp.repec.org/opt/ReDIF/RePEc/rse/wpaper/R5_5_DobreOvidiulliuta_p53_60.pdf

Duffy, M. K., Ganster, D. C., \& Pagon, M. (2002). Social undermining in the workplace. Academy of Management Journal, 45, 331-351. doi:10.2307/3069350

Flyvbjerg, B. (2013). Quality control and due diligence in project management: Getting decisions right by taking the outside view. International Journal of Project Management, 31, 760-774. doi:10.1016/j.ijproman.2012.10.007

Fulghieri P., \& Sevilir, M. (2009). Size and focus of a venture capitalists portfolio. The Review Financial Studies, 22, 4643-4680. doi:10.2139/ssrn.686172

Gaddya, B. E., Sivaram, V. M., Jones, T. B., \& Wayman, L. (2017). Venture capital and cleantech: The wrong model for energy innovation. Energy Policy, 102, 385-395. doi:10.1016/j.enpol.2016.12.035

Glambek, M., Matthiesen, S. B., Hetland, J., \& Einarsen, S. (2014). Workplace bullying as an antecedent to job insecurity and intention to leave: A 6-month prospective study. Human Resource Management Journal, 24, 255-268. doi:10.1111/1748-8583.12035

Glock, C. H., \& Grosse, E. H. (2015). Decision support models for production ramp-up: A systematic literature review. International Journal of Production Research, 53, 6637-6651. doi:10.1080/00207543.2015.1064185

Glock, C. H., Grosse, E. H., \& Ries, J. M. (2017). Decision support models for supplier development: Systematic literature review and research agenda. International Journal of Production Economics, 193, 798-812. doi:10.1016/j.ijpe.2017.08.025

Guo, B., Lou, Y., \& Pérez-Castrillo, D. (2015). Investment, duration, and exit strategies for corporate and independent venture capital-backed start-ups. Journal of Economics \& Management Strategy, 24, 415-455. doi:10.1111/jems.12097

Harris, K. J., Harvey, P., Harris, R. B., \& Cast. M (2013). An investigation of abusive supervision, vicarious abusive supervision, and their joint impacts. The Journal of Social Psychology, 153, 38-50. doi:10.1080/00224545.2012.703709

Harris, R. S., Jenkinson, T., \& Kaplan, S. N. (2014). Private equity performance: What do we know? The Journal of Finance, 69, 1851-1882. doi:10.1111/jofi.12154

Harvey, P., Harris, K. J., Gillis, W. E., \& Martinko, M. J. (2014). Abusive supervision and the entitled employee. The Leadership Quarterly 25, 204-217. doi:10.1016/j.leaqua.2013.08.001

Hochrein, S., Glock, C. H., Bogaschewsky, R., \& Heider, M. (2015). Literature reviews in supply chain management: A tertiary study. Management Review Quarterly, 65, 239-280. doi:10.1007/s11301-015-0113-4 
Hoobler, J. M., \& Hu, J. (2013). A model of injustice, abusive supervision, and negative affect. The Leadership Quarterly, 24, 256-269. doi:10.1016/j.leaqua.2012.11.005

Jackson, W. E., Bates, T., \& Bradford, W. D. (2012). Does venture capitalist activism improve investment performance? Journal of Business Venturing, 27, 342-354 doi:10.1016/j.jbusvent.2011.02.003

Jia, N., \& Wang, D. (2017). Skin in the game: General partner capital commitment, investment behavior and venture capital fund performance. Journal of Corporate Finance, 47, 110-130. doi:10.1016/j.jcorpfin.2017.09.008

Kacmar, K. M., Whitman, M. V., \& Harris, K. J. (2013). The lingering impact of abusive supervision. Journal of Applied Management and Entrepreneurship, 18, 51-71.

Kaplan, S. N., \& Lerner, J. (2010). It ain't broke: The past, present, and future of venture capital. Journal of Applied Corporate Finance, 22, 36-47. doi:10.1111/j.1745-6622.2010.00272.x

Khan, K. S., Kunz, R., Kleijnen, K., \& Antes, G. (2003). Five steps to conducting a systematic review. Journal of the Royal Society of Medicine, 96, 118-121. doi:10.1258/jrsm.96.3.118

Knoll, T., Omar, M. I., Maclennan, S., Hernandez, V., Canfield, S, Yuan, Y., ... Sylvester, R. (2017. Key steps in conducting systematic reviews for underpinning clinical practice guidelines: Methodology of the European Association of Urology. European Urology. Advance online publication. https://doi.org/10.1016/j.eururo.2017.08.016

Korteweg, A., \& Sorensen, M. (2010), Risk and return characteristics of venture capital-backed entrepreneurial companies. The Review of Financial Studies, 23, 3738-3772. doi:10.1093/rfs/hhq050

Lehtonen, O., \& Lahti, T. (2009). The role of advisors in the venture capital investment process. Venture Capital: An International Journal of Entrepreneurial Finance, 11, 229-254. doi:10.1080/13691060902972851

Li, Y., \& Zahra, S. A. (2012). Formal institutions, culture, and venture capital activity: A crosscountry analysis. Journal of Business Venturing, 27, 95-111. doi:10.1016/j.jbusvent.2010.06.003

Liu, D., Liao, H., \& Loi, R. (2012). The dark side of leadership: A three-level investigation of the cascading effect of abusive supervision on employee creativity. Academy of Management Journal, 55, 1187-1212. doi:10.5465/amj.2010.0400

Liu, J., Kwan, H. K., Wu, L., \& Wu, W. (2010). Abusive supervision and subordinate supervisordirected deviance: The moderating role of traditional values and the mediating role of revenge cognitions. Journal of Occupational and Organizational Psychology, 83, 835-856. doi:10.1348/096317909X485216

MacKenzie, C., Garavan, T. N., \& Carbery, R. (2011). Understanding and preventing dysfunctional behavior in organizations: Conceptualizing the contribution of human resource development. Human Resource Development Review, 10, 346-380. doi:10.1177/1534484311417549

Mackey, J. D., Ellen, B. P., Hochwarter, W. A., \& Ferris, G. R. (2013). Subordinate social adaptability and the consequences of abusive supervision perceptions in two samples. The Leadership Quarterly, 24, 732-746. doi:10.1016/j.leaqua.2013.07.003 
Mackey, J. D., Frieder, R. E., Perrewe, P. L., Gallagher, V. C., \& Brymer, R. A. (2015). Empowered employees as social deviants: The role of abusive supervision. Journal of Business and Psychology, 30, 149-162. doi:10.1007/s10869-014-9345-x

Manning, T. (2013). 360 degree assessments of team role behaviours in different contexts. Industrial and Commercial Training, 45, 397-405. doi:10.1108/ICT-04-2013-0024

MaRS. (2013). The due-diligence process in venture capital (VC). Retrieved from https://www.marsdd.com/marslibrary/the-due-diligence-process-in-venture-capital/

Martinko, M. J., Harvey, P., Brees, J. R., \& Mackey, J. (2013). A review of abusive supervision research. Journal of Organizational Behavior, 34, 120-137. doi:10.1002/job.1888

Mawritz, M. B., Mayer, D. M., Hoobler, J. M., Wayne, S. J., \& Marinova, S. V. (2012). A trickle-down model of abusive supervision. Personnel Psychology, 65, 325-357. doi:10.1111/j.17446570.2012 .01246

Metrick, A., \& Yasuda, A. (2011). Venture capital and the finance of innovation (2nd ed.). Hoboken, NJ: Wiley.

Michel, J. S., Newness, K., \& Duniewicz, K. (2016). How abusive supervision affects workplace deviance: A moderated-mediation examination of aggressiveness and work-related negative affect. Journal of Business and Psychology, 31, 1-22. doi:10.1007/s10869-015-9400-2

Mitchell, M. S., \& Ambrose, M. L. (2007). Abusive supervision and workplace deviance and the moderating effects of negative reciprocity beliefs. Journal of Applied Psychology, 92, 11591168. doi:10.1037/0021-9010.92.4.1159

Mitchell, M. S., Vogel, R. M., \& Folger, R. (2015). Third parties' reactions to the abusive supervision of coworkers. Journal of Applied Psychology, 100, 1040-1055. doi:10.1037/apl0000002

Nunes, C. J., Félix, E., \& Pires, C. P. (2011). Which criteria matter most in the evaluation of venture capital investments? Journal of Small Business and Enterprise Development, 21, 505-527, doi:10.1108/JSBED-10-2013-0165

Okoli, C. (2015). A guide to conducting a standalone systematic literature review. Communications of the Association for Information Systems, 37, 879-910.

Olsson, N. O. E., Frydenberg, S., Jakobsen, E. W., \& Jessen, S. A. (2010). In search of project substance: How do private investors evaluate projects? International Journal of Managing Projects in Business, 3, 257-274. doi:10.1108/17538371011036572

Palanski, M., Avey, J.B. \& Jiraporn, N. (2014). The effects of ethical leadership and abusive supervision on job search behaviors in the turnover process. Journal of Business Ethics, 121, 135-146. doi:10.1007/s10551-013-1690-6

Pearce, C. L., \& Manz, C. C. (2014). The leadership disease ... and its potential cures. Business Horizons, 57, 215-224. doi:10.1016/j.bushor.2013.11.005

Rajaeian, M. M., Cater-Steel, A., \& Lane, M. (2017). A systematic literature review and critical assessment of model-driven decision support for IT outsourcing. Decision Support Systems, 102 42-56. doi:10.1016/j.dss.2017.07.002 0167-9236

Rajan, A. T. (2010). Venture capital and efficiency of portfolio companies. IIMB Management Review, 22, 186-197. doi:10.1016/j.iimb.2010.10.009 
Rosenbusch, N., Brinckmann, J., \& Muller, V. (2013). Does acquiring venture capital pay off for the funded firms? A meta-analysis on the relationship between venture capital investment and funded firm financial performance. Journal of Business Venturing, 28, 335-353. doi:10.1016/j.jbusvent.2012.04.002

Sammut, S. M. (2012). What every biotechnology entrepreneur needs to know about VC due diligence. Journal of Commercial Biotechnology, 18, 72-77. doi:10.5912/jcb.533

Schertler, A., \& Tykvova, T. (2011). Venture capital and internationalization. International Business Review, 20, 423-439. doi:10.1016/j.ibusrev.2010.07.009

Shoss, M. K., Einsenberger, R., Restubog, S. L. D., \& Zagenczyk, T. J. (2013). Blaming the organization for abusive supervision: The roles of perceived organizational support and supervisor's organizational embodiment. Journal of Applied Psychology American Psychological Association, 98, 158-168. doi:10.1037/a0030687

Simic, M. (2015). Investment criteria set by venture capitalists. Ekonomski vjesnik/Econviews Review of Contemporary Business, Entrepreneurship and Economic Issues, 28, 457-479.

Strömsten, T., \& Waluszewski, A. (2012). Governance and resource interaction in networks: The role of venture capital in a biotech start-up. Journal of Business Research, 65, 232-244. doi:10.1016/j.jbusres.2010.11.030

Tee, D. D., \& Ahmed, P. K. (2014). 360 degree feedback: An integrative framework for learning and assessment. Teaching in Higher Education, 19, 579-591. doi:10.1080/13562517.2014.901961

Tepper, B. J. (2000). Consequences of abusive supervision. Academy of Management Journal, 43, 178-190. doi:10.2307/1556375

Tepper, B. J., Duffy, M. K., Henle, C. A., \& Lambert, L. S. (2006). Procedural injustice, victim precipitation, and abusive supervision. Personnel Psychology, 59, 101-123.

doi:10.1111/j.1744-6570.2006.00725.x

Tepper, B. J., Moss, S. E., \& Duffy, M. K. (2011). Predictors of abusive supervision: Supervisor perceptions of deep-level dissimilarity, relationship conflict, and subordinate performance. Academy of Management Journal, 54, 279-294. doi:10.5465/AMJ.2011.60263085

Tepper, B. J., Moss, S. E., Lockhart, D. E., \& Carr, J. C. (2007). Abusive supervision, upward maintenance communication, and subordinates' psychological distress. Academy of Management Journal, 50, 1169-1180. doi:10.2307/AMJ.2007.20159918

Thoroughgood, C. N., Tate, B. W., Sawyer, K. B., \& Jacobs, R. (2012). Bad to the bone: Empirically defining and measuring destructive leader behavior. Journal of Leadership \& Organizational Studies, 19, 230-255. doi:10.1177/1548051811436327

Tran, Q., Tian, Y., \& Sankoh, F. P. (2013). The impact of prevalent destructive leadership behaviour on subordinate employees in a firm. American Journal of Industrial and Business Management, 3, 595-600. doi:10.4236/ajibm.2013.37069

Velez, M. J., \& Neves, P. (2017). The relationship between abusive supervision, distributive justice and job satisfaction: A substitutes for leadership approach. Revue Européenne de Psychologie Appliquée 67, 187-198 doi:10.1016/j.erap.2017.05.0051162-9088 
Yagil, D., Ben-Zur, H., \& Tamir, I. (2010). Do employees cope effectively with abusive supervision at work? An exploratory study. International Journal of Stress Management, 18, 5-23. doi:10.1016/j.leaqua.2013.08.001

Yung, C. (2009). Entrepreneurial financing and costly due diligence. Financial Review, 44, 137-149. doi:10.1111/j.1540-6288.2008.00213.x

Zhang, J. (2011). The advantage of experienced start-up founders in venture capital acquisition: Evidence from serial entrepreneurs. Small Business Economic, 36, 187-208. doi:10.1007/s11187-009-9216-4

Zhang, T. X., Aksu, B. P., \& Wang, H. (2012). Conflicts of interest in venture capital-backed IPO firms. Journal of International Finance \& Economics, 12, 50-59.

The International Journal of Applied Management and Technology (IJAMT), sponsored by Walden University's School of Management, is a peer-reviewed, online journal that addresses contemporary national and international issues related to management and technology. The objectives of the IJAMT are to: (a) encourage collaborative and multi-disciplinary examinations of important issues in business and technology management, and (B) engage scholars and scholar-practitioners in a dynamic and important dialogue.

Walden University Publishing: http://www.publishing.waldenu.edu 